\title{
Odontopleurid trilobites of the Katian/Hirnantian boundary interval in the Prague Basin (Bohemia)
}

\author{
MICHAL MERGL
}

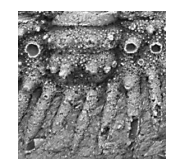

\begin{abstract}
A new association of odontopleurid trilobites is described from calcareous claystone to marlstone, the so-called "Perník Bed”, of the topmost part of the Králův Dvưr Formation. The association includes Diacanthaspis krizi sp. nov., associated with Bojokoralaspis peregrina (Barrande, 1872) and other rare and poorly known odontopleurids preliminary referred to Chlustinia Přibyl \& Vaněk, 1965, Proceratocephala Prantl \& Přibyl, 1949 and Eoleonaspis Sheng, 1974. This association indicates a closer relationship to the late Katian and early Hirnantian odontopleurid faunas of Baltica and Avalonia than to those of Armorica (Spain, Sardinia), where the genera Calipernurus Whittington, 1956a, Diacanthaspis Whittington, 1941, Dicranurus Conrad, 1841, Hispaniaspis Hammann, 1992, Radiaspis Richter \& Richter, 1917, and Whittingtonia Prantl \& Přibyl, 1949 are present in carbonatic buildups of the late Katian age. It is assumed that the deposition of "Perník Bed" is a result of the early Hirnantian sea level lowering and not of the warming related to the Boda event. • Key word: Diacanthaspis, odontopleurids, Ordovician, Katian, Hirnantian, Prague Basin.
\end{abstract}

MERGL, M. 2014. Odontopleurid trilobites of the Katian/Hirnantian boundary interval in the Prague Basin (Bohemia). Bulletin of Geosciences 89(2), 401-412 (5 figures). Czech Geological Survey. Prague, ISSN 1214-1119. Manuscript received May 21, 2013; accepted in revised form March 28, 2014; published online May 7, 2014; issued May 19, 2014.

Michal Mergl, Centre of Biology, Geosciences and Environmental Sciences, Faculty of Education, University of West Bohemia in Plzeň, Klatovská 51, 30619 Plzeň, Czech Republic; mmergl@cbg.zcu.cz

The Králův Dvůr Formation is a lithostratigraphical unit probably representing the Upper Katian interval (called also Kralodvorian Regional Stage) in the Prague Basin of the Czech Republic (Havlíček \& Vaněk 1966, Havlíček 1982, Havlíček et al. 1994, Fatka \& Mergl 2009, Budil et al. 2011b). Diverse, mainly deep-water faunal associations include common cyclopygid and remopleuridid trilobites (see Shaw 2000; Budil et al. 2011a, b; Mergl 2011c), moderately diverse small-sized deep-water brachiopods (see Havlíček 1967, 1977), ostracods, gastropods, hyolithids, nuculoid bivalves and cephalopods. The rather deeper-water character of the fauna is emphasized by the absence of large strophomenate brachiopods, bryozoans and pelmatozoans which are characteristic for the rich Katian (Ashgillian) faunas in the SW Europe (Iberian Chains, Central-Iberian zone, Asturias, Montagne Noire, Carnic Alps, Sardinia, Morocco) (Havlíček 1981; Villas 1985, 1995; Leone et al. 1991; Vennin et al. 1998; Villas et al. 2002, 2006; Jiménez-Sánchez et al. 2007; Colmenar et al. 2013 and others).

Unlike the underlying sequence, the topmost part of the Králův Dvůr Formation yields a distinctive fauna, with diverse trilobites, ostracods, medium-sized strophomenate brachiopods, large gastropods, machaeridians, bryozoans, cystoids, blastoids and other fossils (Havlíček \& Vaněk 1966, Havlíček \& Mergl 1982, Štorch \& Mergl 1989). This fauna occurs in a thin bed of carbonate claystone to marlstone (so-called "Perník Bed"), which is immediately followed by a carbonate claystone bearing the unambiguous Hirnantian shelly fauna (Mergl 2011a). The fauna of the "Perník Bed" is distinctive in containing several species of odontopleurid trilobites, among which presence of Diacanthaspis is significant.

\section{Geological setting}

The "Perník Bed" (perník = gingerbread) is a slang name for the unusually rich fossiliferous but thin carbonate claystone to marlstone occurring in the top part of the Králův Dvůr Formation (Štorch \& Mergl 1989, pl. 1). This bed has been interpreted as being the result of climatic and glacioeustatic changes near the Katian/Hirnantian boundary (Brenchley \& Štorch 1989). The bed thickness and its fossil content, although generally uniform, gently differ at particular localities. Shelly fossils are largely allochthonous in all localities. Bioclasts are fragmented, deformed, and are randomly oriented in the sediment. Graded sorting of fossils is present in individual layers and smaller bioclasts are concentrated in paved layers. The fine-grained sediment and presence of minute sorted fossils suggest a deeper shelf environment reached by recurrent suspension streams. Trace fossils penetrate the top of the claystone level, with dragged out bioclasts 


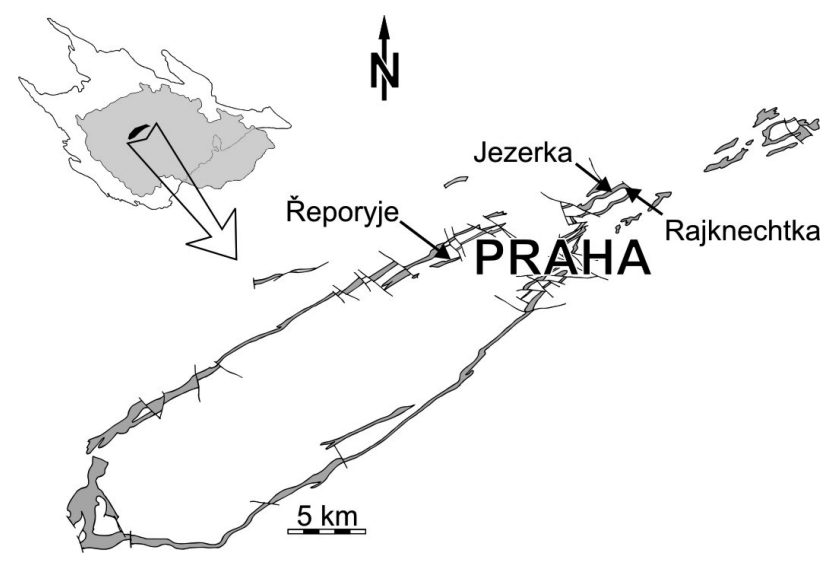

Figure 1. Distribution of the Králův Dvůr Formation (Upper Katian) in the Prague Basin with the location of referred localities.

but leaving the deeper part of claystone intact. The taxonomy of fossils from the "Perník Bed" is well known (Marek 1952, 1964, 1989; Havlíček 1967, 1977; Havlíček \& Mergl 1982; Frýda 1989; Shaw 1995, 2000; Ferretti 1998; Mergl 2011b, 2012). The general importance of this fauna has been reviewed by Havlíček \& Vaněk (1966), Havlíček (1982, 1989), and Štorch \& Mergl (1989).

The carbonate claystone grades upward into claystone beds with more abundant coarse siliciclastic detritus. These layers contain a different low-diversity fauna, dominated by ostracods, machaeridians, few orthid brachiopods, and especially the trilobite Mucronaspis grandis (Barrande, 1852). The presence of brachiopods Kinnella kielanae (Temple, 1965) and Hirnantia sagittifera (M'Coy, 1851) and graptolite Metabolograptus ojsuensis (Koren \& Mikhaylova, 1980) confirms the Hirnantian age of this claystone (Štorch 2006, Mergl 2011a).

Newly described species of Diacanthaspis was sampled in the "Perník Bed" in three artificial outcrops. The two sampling sites, the Jezerka and Rajtknechtka localities on territory of Prague have been investigated by Vladimír Havlíček in 1979 and 1982, respectively. Both were described in detail by Storch \& Mergl (1989) with their fauna commented by Havlíček \& Mergl (1982). The third locality, a temporary outcrop in Praha- ̌eporyje has been discovered by Jiří Kř́iž and subsequently sampled by Petr Budil and the author in 2007. Its fauna has been preliminary described by Mergl (2011b, 2012).

The supposed inner shelves of the Prague Basin were possibly narrow in Sandbian time and were continuously supplied by siliciclastic detritus, with confined carbonate deposition. The Katian-aged shallow margins of the basin are not preserved and deep outer shelf environment dominated over now preserved part of the Prague Basin. Shoals on summits of tectonically controlled submarine elevations existed in the Sandbian and early Katian, but these shoals were probably strongly affected by submarine storm-gen- erated erosion (Havlíček 1982, Havlíček \& Štorch 1990). This, temporary available shallow environment inhabited the brachiopod-bryozoan-pelmatozoan (BBP) associations but the carbonate buildups never started to develop there. It is very probable that these elevations were developed and destroyed already before onset of the supposed Boda warming event (sensu Fortey \& Cocks 2005, for alternative interpretation of this event as a global cooling, see Cherns \& Wheeley 2007).

Specimens of the newly described species of Diacanthaspis were sampled in the "Perník Bed" in three excavated outcrops. The two sampling sites, the Jezerka and Rajtknechtka localities on territory of Prague have been investigated by Vladimír Havlíček in 1979 and 1982, respectively. Both localities were described in detail by Štorch \& Mergl (1989) and discussed by Havlíček \& Mergl (1982). The third locality, a temporary outcrop in Praha-ŘReporyje was discovered by Jiří Křriž and subsequently sampled by Jiří Vaněk, Petr Budil, Jan Valíček, and the author in 2007. The fauna has been preliminary described by Mergl (2011b, 2012).

\section{Material and methods}

Figured specimens are stored in the palaeontological collections of the University of West Bohemia in Plzeň, Plzeň (PCZCU). Due to their minute size, most of the specimens were photographed with utilization of Quick Photo Deep Focus software and Olympus SX51 binocular lens. Latex casts were only made in a few cases because of the softness of the mudstone and possible damage of specimens. Morphological terminology used follows Whittington et al. (1997).

\section{Systematic palaeontology}

Family Odontopleuridae Burmeister, 1843

Remarks. - Five species of odontopleurid trilobites have been sampled from the "Perník Bed", but only one is described as a new species. In addition to the often-cited Acantholoma mirka Marek, 1952 (Kielan 1960, Bruton 1968, Šnajdr 1984, Shaw 2000), three other species have since been recognised. However, they are represented by rare and poorly preserved specimens. Therefore, they are only briefly commented and illustrated.

Subfamily Odontopleurinae Burmeister, 1843

\section{Genus Bojokoralaspis Šnajdr, 1984}

Type species. - Bojokoralaspis koral Šnajdr, 1984. Upper Ordovician, Sandbian, Zahořany Formation, Prague Basin, Bohemia. 
Discussion. - Pek \& Vaněk (1989), and especially Ramsköld \& Chatterton (1991, p. 357) and Vaněk (2001, p. 66) intimated that Bojokoralaspis Šnajdr 1984 may be a junior subjective synonym of Eoleonaspis Sheng, 1974. This opinion was not discussed by Shaw (2000) but was shared by Vaněk \& Valíček (2001) and Jell \& Adrain (2002). A solution of this quite complicated question is still lacking (but see Vaněk 2001) and is not discussed herein. Provisionally, I propose to retain the name Bojokoralaspis for the three species occurring in the Prague Basin and to several species referred to Primaspis outside Bohemia. Unlike two early Sandbian Primaspis species known from the Prague Basin of Bohemia, Primaspis ascitus (Whittington, 1956a) from Virginia, P. multispinosa Bruton, 1965 from Norway, P. evoluta (Törnquist, 1884) from Norway, Sweden, Latvia (Bruton 1965, 1966, 1968; Suzuki et al. 2009), and Primaspis sp. from Belgium (Lespérance \& Sheehan 1987) and Kazakhstan (Apollonov 1980) lack paired occipital spines. These species should be referred to Bojokoralaspis (sensu Šnajdr 1984) because, unlike Primaspis, all cranidia lack occipital spines.

\section{Bojokoralaspis peregrina (Barrande, 1872) Figure 4A-D}

1872 Acidaspis peregrina Barrande; Barrande, p. 79, pl. 12, figs 30,31 .

1949 Primaspis peregrina (Barrande). - Prantl \& Přibyl, p. 148.

1952 Acantholoma mirka Marek; Marek, p. 436, pl. 2, fig. 3.

1966 Primaspis (Primaspis?) peregrina (Barrande, 1872). - Přibyl \& Vaněk, pl. 5, fig. 4.

1968 Primaspis peregrina Barrande. - Bruton, p. 13, pl. 2, fig. 5.

1984 Primaspis (Bojokoralaspis) musca (Barrande, 1846). - Šnajdr, p. 55, pl. 10, figs 8, 9.

2000 Bojokoralspis peregrina (Barrande, 1872). - Shaw, p. 379, pl. 2, figs 2-8.

2001 Eoleonaspis peregrina (Barrande, 1872). - Vaněk, p. 66.

2001 Eoleonaspis peregrina (Barrande, 1872). - Vaněk \& Valíček, p. 36.

Material. - Six cranidia, three librigenae, and four pygidia.

Discussion. - New sampling from the "Perník Bed" has yielded numerous specimens of Bojokoralaspis (Fig. 4A-D) which in size are much larger compared to the new species of Diacanthaspis. If this material belongs to $B$. peregrina (Barrande, 1872) as suggested by Shaw (2000) or whether it is a synonym of B. mirka (Marek, 1952) is uncertain and other authors have recently considered it to be a junior subjective synonym of Eoleonaspis olini (Troedsson, 1918) fide Ramsköld \& Chatterton (1991, p. 366), Vaněk (2001, p. 66) and Vaněk \& Valíček (2001, p. 36). This possible synonymy was already suspected by Kielan (1960) and Bruton (1966). In addition, the relation of Bojokoralaspis specimens from the "Perník Bed" to B. vondraceki Šnajdr, 1987 from the uppermost part of the Kosov Formation (late Hirnantian) in unclear. This species, informally reported already by Marek (1951) and formally described by Šnajdr (1987), most likely belongs to another genus.

Occurrence. - Upper Katian, the top of the Králův Dvůr Formation ("Perník Bed”); localities Králův Dvůr (Kosov), Levín, Praha-Řeporyje, and Vráž.

\section{Genus Chlustinia Přibyl \& Vaněk, 1965}

Type species. - Odontopleura keyserlingi Barrande, 1846. Upper Ordovician, Sandbian, Zahořany Formation, Prague Basin, Bohemia.

\section{Chlustinia? sp.}

Figure 4F

Discussion. - Chlustinia is suggested as an endemic Bohemian genus (Šnajdr 1984), with the first report from the Zahořany Formation (late Sandbian or early Katian). Its latest occurrence is reported in the middle to early late Katian (Podolí ore horizon at the base of the Králův Dvưr Formation; Šnajdr 1982). The single pygidium of Chlustinia? sp. coming from the "Perník Bed" (Fig. 4 F) is very probably related to poorly known $C$. mikulasi Šnajdr, 1982 from the Podolí ore Horizon. The shape of principal spines in the newly collected pygidium differs from those of $C$. keyserlingi (Barrande, 1846) present in the Zahořany Formation (late Sandbian to earliest Katian) and from C. detecha Šnajdr, 1984 present in the Bohdalec Formation (early to middle Katian). Chlustinia? sp. is remarkably similar to Primaspis sp. indet. described by Price (1980) from the Ashgillian (Katian) of Wales.

\section{Genus Diacanthaspis Whittington, 1941}

Type species. - Diacanthaspis cooperi Whittington, 1941; Upper Ordovician, Sandbian, Lower Martingsburg Formation, Virginia, USA.

Material. - One pygidium.

Remarks. - The presence of Diacanthaspis sp. in the "Perník Bed" has been discussed by Mergl (2011a). Another odontopleurid from the same stratigraphic level referred by 


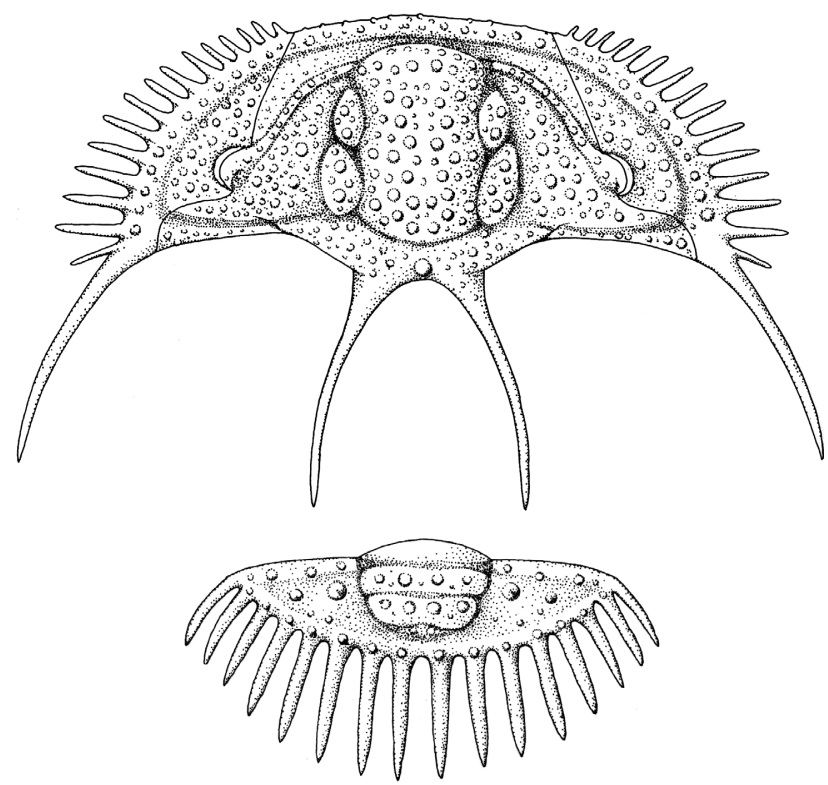

Figure 2. Diacanthaspis krizi sp. nov. Reconstruction of cephalon and pygidium; approximately $\times 15$.

Šnajdr (1984), Štorch \& Mergl (1989) and by Shaw (2000), belongs to the genus Bojokoralaspis and has been also reported by Marek (1952).

Occurrence. - Upper Katian, the top of the Králův Dvưr Formation ("Perník Bed"); locality Praha-Řeporyje.

\section{Diacanthaspis (D.) krizi sp. nov.}

Figures 2, 3

Holotype. - Pygidium, internal and external mould figured on Fig. 3O, W (PCZCU 1874).

Type horizon. - Upper Katian, the top of the Králův Dvůr Formation ("Perník Bed").

Type locality. - Praha-̌̌eporyje, temporary excavation done in 2007.
Etymology. - In honour of Jiři Kř́žz, the prominent Czech palaeontologist.

Material. - Twenty cranidia, ten librigenae, sixteen pygidia, two incomplete segments and incomplete part of the thorax with five segments, all preserved as internal and external moulds in claystone.

Diagnosis. - Diacanthaspis with thin and long occipital spines, a long inward curved librigenal spine, twelve long librigenal border spines, a distinct longitudinal row of spines on librigenal border, undivided pleural field in pygidium, and eight long border spines of uniform size in pygidium.

Description. - Species small-sized, maximal estimated sag. length of entire specimen does not exceed $6 \mathrm{~mm}$. Cranidium strongly vaulted (sag. and tr.), semicircular in outline, sag. length including the occipital ring without spines is $2 \mathrm{~mm}$. Glabella inclusive the occipital ring broadly ovoid in outline, with the maximum width across L1. Glabella strongly arched (tr. and sag.), well limited by deep axial furrows. Three glabellar lobes distinct. L1 largest, ovoid, twice as long as wide, strongly arched (sag. and tr.), well separated from the median glabellar lobe by unevenly deep S1. L2 about one-third size of L1, directed anteromesially. $\mathrm{S} 2$ distinct and deep. L3 is connected with the frontal lobe, distinct as a small node on anterolateral slope of the frontal lobe. Anterior margin of glabella gently rounded. Median glabellar lobe subrectangular, gently constricted opposite to L1 and L2 and slightly expanding in antrolateral corners. Occipital furrow deep and broad. Occipital ring convex (tr. and sag.), mesially widened (sag.), occupying some $20 \%$ of cranidial length. Occipital lobes small. Long tubular paired occipital spines as long as glabella. Spines posterolaterally directed, with gently upward curved proximal and inward curved distal parts. Median occipital organ distinct. Tubercles on the glabella large, circular, showing paired spacing, otherwise without distinct paired or other regular spacing. L1 and L2 with two larger tubercles. Interspaces between large and medium-sized tubercles covered by very fine evenly sized and randomly spaced spines. Fine spines cover also a floor of axial and border furrows. Fixigenae raised,

Figure 3. A-X - Diacanthaspis krizi sp. nov. $\bullet$ A, D - cranidium, internal mould in dorsal and oblique views, PCZCU 1866 . $\bullet$ B - cranidium, internal mould, PCZCU 1868. • C - cranidium, latex cast of exterior, PCZCU 1842. • E - cranidium, internal mould, PCZCU 1886 . $\bullet$ F - incomplete cranidium, internal mould, PCZCU $1879 . \bullet \mathrm{G}$ - incomplete cranidium, internal mould with remains of exoskeleton, PCZCU 1884 . $\bullet \mathrm{H}-$ incomplete cranidium, internal mould, PCZCU 1863 . $\bullet$ I - incomplete segment from the posterior part of thorax, internal mould, PCZCU 1890 . $\bullet$ - fragment of segment, internal mould, PCZCU 1891. • K - incomplete cranidium, external mould, PCZCU 1867 . $・$ L - right librigena, internal mould, PCZCU 1882. • M - right librigena, internal and external moulds, PCZCU 1888. • O,W - pygidium, external and internal moulds, PCZCU 1874. $\bullet \mathrm{P}, \mathrm{S}$ - pygidium, latex cast of exterior and internal mould, PCZCU $1873 . \bullet \mathrm{Q}-$ pygidium, internal mould, PCZCU $1872 . \bullet \mathrm{R}-$ pygidium, latex cast of exterior, PCZCU 1889. • T - pygidium, internal mould, PCZCU 1876. • U - pygidium, internal mould, PCZCU 1875 . $・$ V-pygidium, internal mould, PCZCU 1869. - X - pygidium, internal mould, PCZCU 1870. Stratigraphic and geographic location: The top of the Králův Dvůr Formation, "Perník Bed". Localities: Praha-Řeporyje (A-D, F, I-X), Praha-Jezerka (G, H), and Praha-Rajtknechtka (E). Bars equal to 1 mm. All photos by the author. 


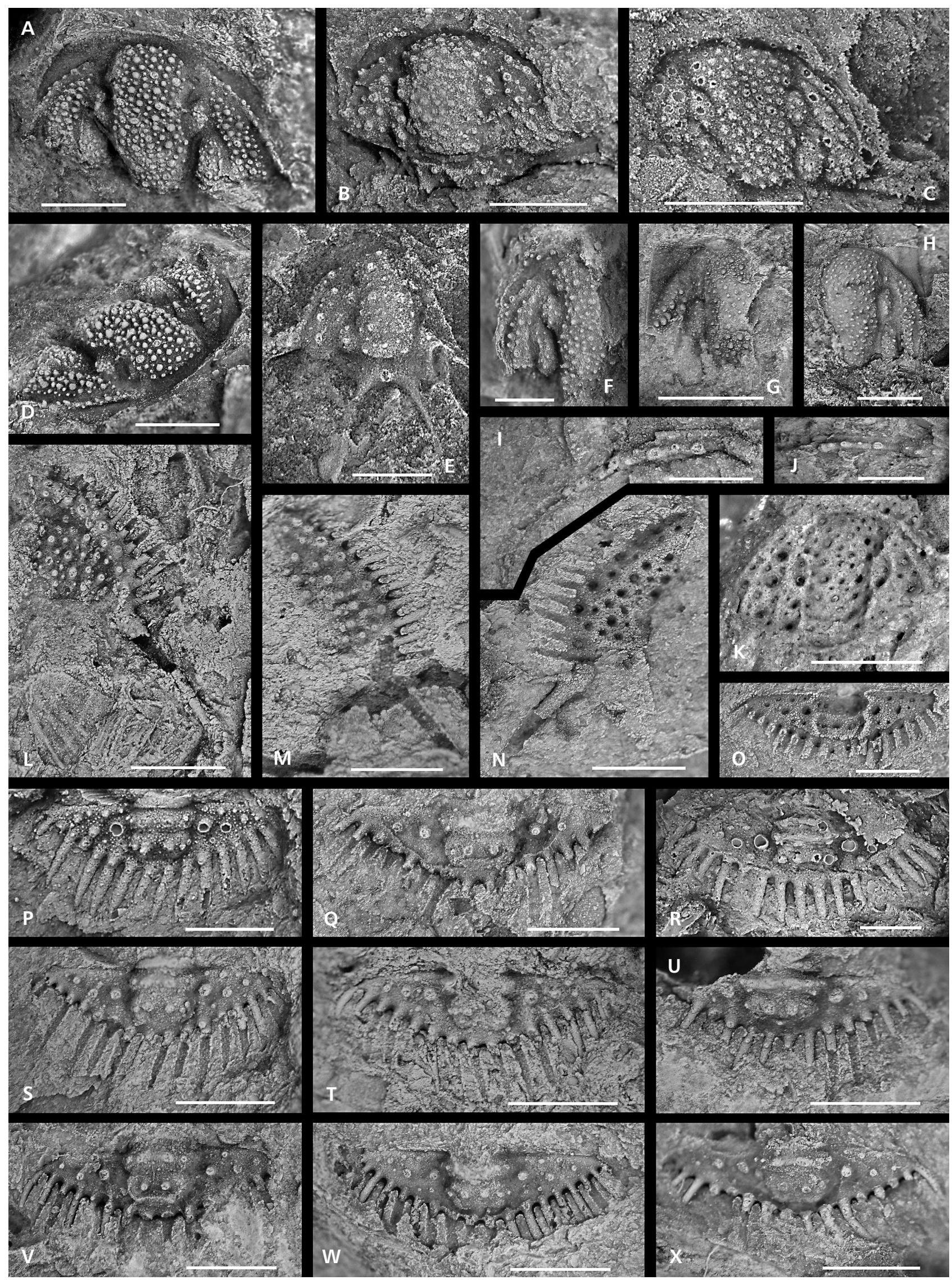


narrow, gently arched (tr.). Posterior border widens laterally. Posterior border furrow deep and narrow (sag.), becoming wider and shallower laterally. Ocular ridge distinct, narrow, obliquelly backwards curving and separated from inner field of fixigena by a deep furrow devoid of large tubercles. Inner genal field narrowly triangular, with surface bearing large tubercles in three to five oblique rows. Palpebral lobes weakly developed, small, highly raised above surface of fixigena, situated about opposite midlength of L1. Anterior branches of suture gently subparallel anteriorly, running along the edge of ocular ridge. Anterolateral field of fixigena outside the ocular ridge triangular, highly raised. Anterior border narrow (sag.), highly raised, separated by a deep narrow border furrow.

Librigenae triangular, with flat surface and gently rounded lateral border becoming wider toward the librigenal spine. Eye supported by a low stalked eye socle. Librigenal spine thin and long, swollen at the base, directed outwards, gently curved. Short notch present inside the base of the librigenal spine. Border with at least twelve thin forward to outwards directed border marginal spines. The first anterior border marginal spine short and thin. The size and and length of border marginal spines increase backwards. The most posterior border marginal spine shorter than others and situated opposite to the notch of the librigenal spine. Outer surface of the border with single longitudinal row of dorsally directed short spinose tubercles. Cheek surface with larger spinose tubercles, having interspaces with fine spines.

Thoracic segments short (sag.), with significantly vaulted axis and subhorizontal pleurae. Principal pleural ridge with five vertical spines. Axis with short spines. Principal pleural spine short, directed laterally in anteriormost segments. The posterior thoracic segments with long and strongly backward curved pleural spine.

Pygidium of semielliptical outline (border spines included) twice as long (sag.) as wide, with straight anterior margin and gently curved posterior margin. Maximum width including border spines at about anterior third. Pleural area flat, narrowly triangular, without distinct pleural ridge. Axis moderately convex, prominent, bordered by narrow and deep axial furrows. The axis is subquadrate in a plan view, lowering backwards, anteriorly occupying one-fourth of the anterior pygidial margin. Articulation half ring short. Two axial rings present, weakly divided by a shallow and narrow furrow. The first axial ring prominent, strongly arched (sag.), about one third long (sag.) as wide (tr.). The second axial ring slightly narrower (tr.), and slightly longer than the first axial ring, gently arched (tr.). Each axial rings bear a pair of large tubercles. The first ring has three additional pairs of smaller tubercles placed laterally to large tubercles and a median small tubercle in the axial line. Each large tubercle at the second axial ring laterally associated with two smaller tubercles. Pleural field un- divided, with flat surface bearing symmetrically arranged tubercles. Large upward directed tubercle symmetrically situated opposite to interring furrow on pleural field. Three to four smaller tubercles arranged in a row along the anterior margin of the pygidium. Additional three to four smaller tubercles present on the flat surface of the each pleural field. Short spinose upward directed tubercle is situated near the base of each border spine with the exception of the most lateral spine. Border spines cylindrical in section, long, evenly sized and radially arranged, weakly tapering distally, with acute tips. Distal tips of spines weakly curved downwards. There are usually eight spines along the posterior border but pygidia with seven or nine pairs of spines, respectively, have been observed. Surface of axis and pleural fields between tubercles is covered by minute spines. Very fine spines cover surface of border spines.

Discussion. - Several late Katian species of Diacanthaspis similar to the new species are known outside the Prague Basin. Hammann (1992) described Diacanthaspis conica Hamman, 1992 and D. margaritata Hammann, 1982 from the Rebosilla Member of the Iberian Chains (upper Katian, Spain). Diacanthaspis conica differs from D. krizi in possessing distinctly shorter border spines at the librigena, a well developed occipital organ, shorter paired occipital spines and by distinctly shorter and fewer marginal spines on the pygidium. Diacanthaspis krizi sp. nov. has the marginal spines on pygidium twice longer than those present in D. conica. Although one pygidium having seven spines occurs in the type collection of $D$. krizi, the majority of pygidia show eight spines. Librigena of D. krizi has a longitudinal row of upwardly directed spinose tubercles on the librigenal border. Librigena of $D$. conica figured by Hammann (Hammann 1992, pl. 34, figs 4, 5) exhibits longer spines than illustrated on the reconstruction (Hammann 1992, text-fig. 32). Figures also show a distinct row of upwardly directed spines on the librigenal border (Hammann 1992, pl. 34, fig. 4) but they are considerably shorter than those on librigena of D. krizi. Diacanthaspis margaritata has larger tubercles on the cephalon and pygidium than D. krizi and they are more closely spaced forming a rosette pattern. Librigenal spine of D. margaritata is more robust than that of $D$. krizi and the dorsal surface of librigena is covered by thicker and much larger tubercles. Pygidium of D. margaritata is distinct by shorter, more stout and less numerous posterior spines.

Diacanthaspis tariccoi Hammann \& Leone, 2007 was decribed from the Portixeddu Formation, at locality Ovile Cannamenda (Can 1c) of Sardinia only (Hammann \& Leone 2007). This species is similar to D. krizi in having a densely tuberculate ornamentation, distinct longitudinal row of spinose tubercles on librigenal border, long and numerous border spines at librigena, paired occipital spines and by similar outline of the pygidium. Diacanthaspis 
tariccoi has fourteen posterior border spines on the pygidium while $D$. krizi has sixteen to eighteen spines. However, one pygidium of $D$. krizi is known with fourteen spines but there are always only twelve spines of subequal size in $D$. tariccoi, having the first anterior pair distinctly smaller then other spines. Occipital spines of D. krizi are slender and distinctly longer than those of $D$. tarricoi.

Diacanthaspis sladensis (Reed, 1905) from the base of the Haverford Mudstone Formation of Wales (Cocks \& Price 1975) and the top of the Keisley Limestone (Temple 1969 ) is other species similar to $D$. krizi. The pygidium of $D$. sladensis has, as well as the pygidium of D. krizi, sixteen posterior spines. $D$. krizi has shorter occipital spines than the lectotype cranidium of $D$. sladensis illustrated by Cocks \& Price (1975, pl. 82, fig. 10). D. krizi seems to be related to $D$. sladensis but morphology of the latter species is not sufficiently known.

Bruton (1968) described three unassigned species of Diacanthaspis from Estonia. The pygidium of Diacanthaspis sp. indet. B from the Oandu Stage (early Katian) of Estonia is remarkably similar to the pygidium of $D$. krizi. There is almost the same arrangement of tubercles on the pleural fields and two pairs of large tubercles on each axial rings. The main difference between both species is the presence of only fourteeen marginal spines in this taxon (Bruton 1968; Fig. 5B, C) compared to D. krizi. Another pygidium and the librigena referred to Diacanthaspis sp. indet. C are also similar to $D$. krizi, but it is more rectangular and differs by only fourteen marginal spines. Diacanthaspis sp. indet. B and $D$. sp. indet. C are not well preserved and are hardly comparable with the present new species. They are stratigraphically earlier coming from the Sandbian and early to mid-Katian. All species of Diacanthaspis described by Whittington (1956a) from the Middle Ordovician of Virginia strikingly differ from D. krizi, mainly by distinctly developed major spines in pygidium. The type species $D$. cooperi Whittington, 1941 differs from D. krizi mainly by six pairs of marginal spines and by a development of major spine on upper surface of pygidium.

Occurrence. - Upper Katian, the top of the Králův Dvůr Formation ("Perník Bed"); locality Praha-̌̌eporyje, Praha-Rajtknechtka, Praha-Jezerka.

\section{Genus Eoleonaspis Sheng, 1974}

Type species. - Acidaspis shanensis Reed, 1915. Upper Ordovician, Hirnantian, Pangsha-pye Formation, Burma.

\section{Eoleonaspis? sp.}

Figure 4E

Material. - Two cranidia.

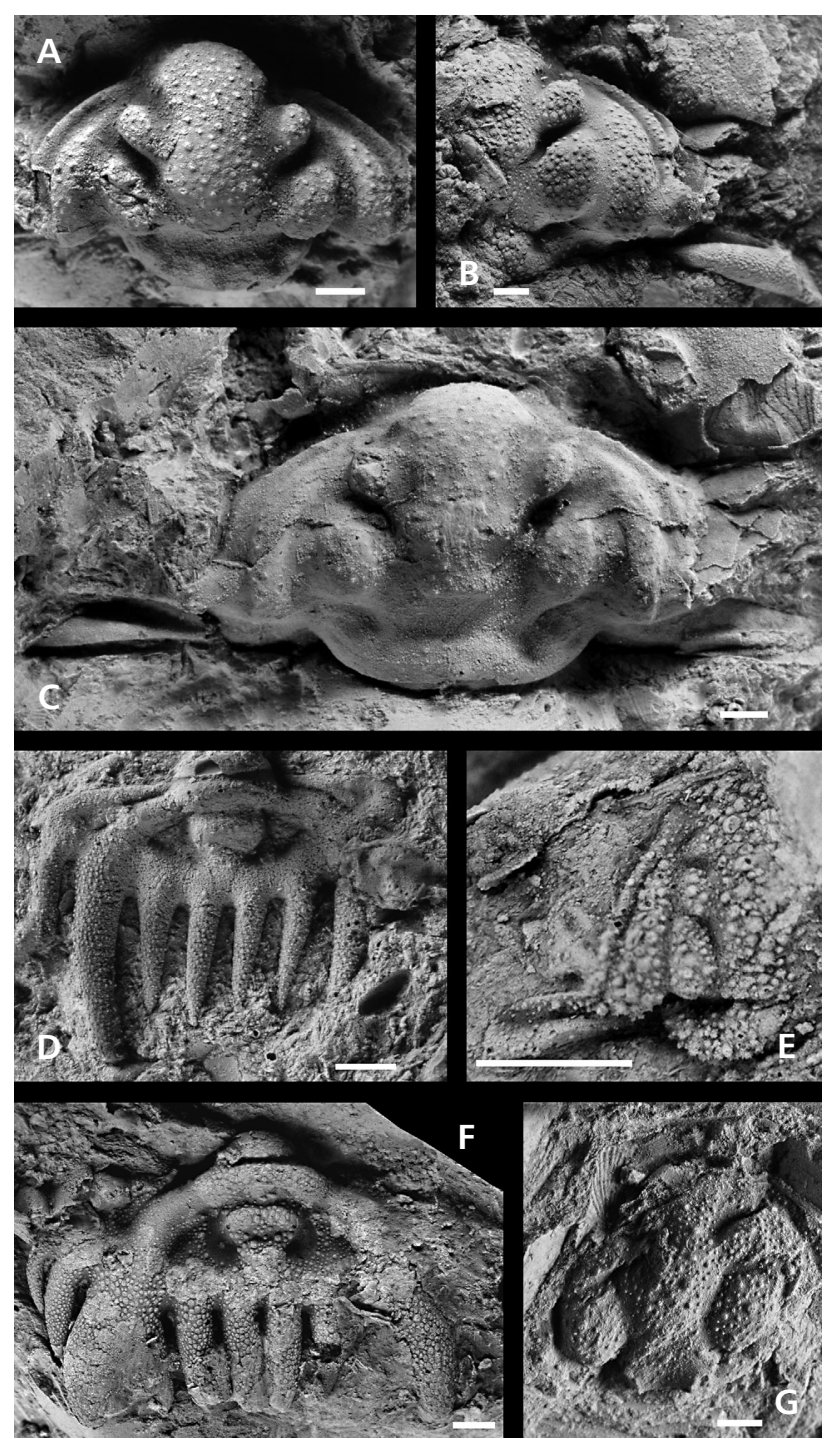

Figure 4. A-D - Bojokoralaspis peregrina (Barrande, 1872). • A - cranidium, internal mould, PCZCU 1892. • B, C - cranidium, latex cast of exterior and internal mould, PCZCU 1893 . $・$ D - pygidium, latex cast of exterior, $\mathrm{PCZCU}$ 1894. • E - Eoleonaspis sp., cranidium, latex cast of exterior, PCZCU 1895. • F - Chlustinia? sp., pygidium, latex cast of exterior, PCZCU 1896. $\bullet \mathrm{G}-$ Proceratocephala? sp., incomplete cranidium, internal mould, PCZCU 1987. The top of the Králův Dvůr, "Perník Bed". Locality: Praha-Řeporyje. Bars equal to $1 \mathrm{~mm}$. All photos by the author.

Remarks. - A small-sized odontopleurid distinguished by absence of the occipital spines and less distinctive L1 and L2 has been sampled in the "Perník Bed" (Fig. 4 E). This material is remarkably similar to the type specimens of Eoleonaspis shanensis (Reed, 1915) redescribed also by Cocks \& Fortey (2002) from the Hirnantian of Burma. Cranidia from the "Perník Bed" are also strikingly similar to "Bojokoralaspis" vondraceki of the latest Hirnantian age (Šnajdr 1987). However, "B." vondraceki is not sufficiently known and probably belongs to Eoleonaspis Sheng, 1974 (see also discussion of 


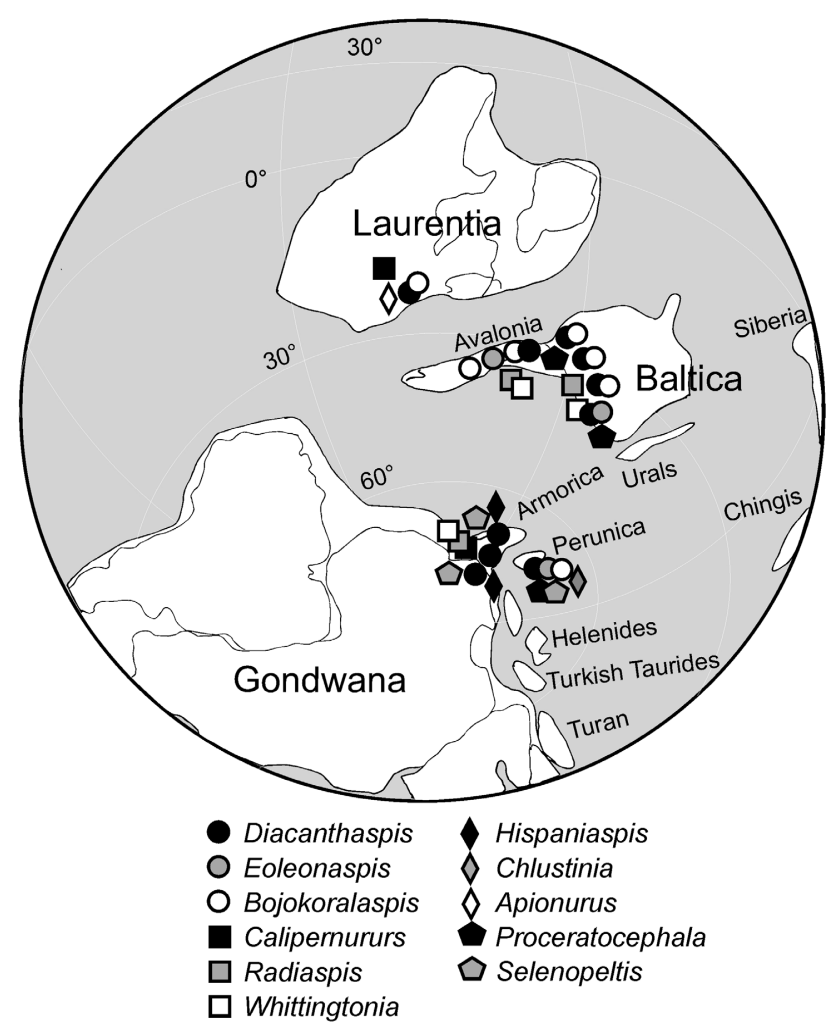

Figure 5. Palaeogeographical reconstruction for the Katian (after Popov et al. 2013, modified) showing geographical distribution of the Middle and Late Ordovician odontopleurid trilobites. Data mainly after Bruton (1965, 1966, 1968), Hammann (1992), Hammann \& Leone (2007), Kielan (1960), Lesperance \& Sheehan (1987), Price (1980), Šnajdr (1984), and Whittington (1956a).

Bojokoralaspis herein). New specimens are similar to specimens referred to Eoleonaspis olini (Troedsson, 1918) by Kielan (1960) and Bruton (1966) and to several other species referred to Eoleonaspis of the Hirnantian to Llandoverian age (Reed 1915, Apollonov 1980, Curtis \& Lane 1998; see comments of Cocks \& Fortey 2002). Taxonomical and phylogenetic problems regarding Eoleonaspis and its relation to Primaspis have been discussed by Cocks \& Fortey (2002), who noted, that the cladistic analysis of Ramsköld \& Chatterton (1991) likely requires a reworking.

Occurrence. - Earliest Hirnantian, the top of the Králův Dvůr Formation ("Perník Bed"); locality Praha-Řeporyje.

Subfamily Miraspinae Richter \& Richter, 1917

\section{Genus Proceratocephala Prantl \& Přibyl, 1949}

Type species. - Acidaspis terribilis Reed, 1914. Upper Ordovician, Katian, Drummuck Group, Starfish Bed, Scotland.

\section{Proceratocephala? sp. Figure 4G}

Material. - One cranidium.

Remarks. - The poorly preserved cranidium belongs to medium sized odontopleurid (Fig. 4G). Presence of two robust occipital spines, large L1 and L2, and weak and uneven spinosity may be indicative of Miraspidinae Richter \& Richter, 1917. The specimen is provisionally referred to Proceratocephala Prantl \& Přibyl, 1949, a genus known from the Katian of Scotland (Reed 1914, Whittington 1956b), and Poland (Kielan 1960).

Occurrence. - Upper Katian, the top of the Králův Dvůr Formation ("Perník Bed"); locality Praha-̌̌eporyje.

\section{Discussion}

To compare with previous stage of knowledge (Štorch \& Mergl, 1989, Shaw 2000), the odontopleurid association of the Katian/Hirnantian boundary strata is substantially more diversified in the Prague Basin. This association in the "Perník Bed" clearly differs from older (Sandbian to midKatian) odontopleurid associations of the Prague Basin by absence of Selenopeltis and first occurrence of minute odontopleurinids (Diacanthaspis, Eoleonaspis) and a miraspidinae Proceratocephala. Sandbian and mid-Katian representatives of the Odontopleuridae Burmeister, 1843 in Bohemia belong to genera Bojokoralaspis, Chlustinia, Primaspis, and Selenopeltis Hawle \& Corda, 1847. Of these, Selenopeltis occurs as early as Darriwilian (Šárka Formation) with the latest possible record from early late Katian (lower to middle parts of the Králův Dvůr Formation: Šnajdr 1984, Shaw 2000, Bruton 2008). Primaspis is restricted to the Sandbian-lowermost Katian (Libeň to Zahořany formations; Šnajdr 1984). Chlustinia ranges from the late Sandbian to probably early upper Katian. Bojokoralaspis is known from the Sandbian to the latest Katian (Šnajdr 1984).

Unlike in Bohemia, Bojokoralaspis, Chlustinia, Eoleonaspis and Proceratocephala are absent among the late Katian odontopleurids of European peri-Gondwana and NW Gondwana (= present day SW Europe and NW Africa). Here, the odontopleurid trilobites are represented by particular species of Diacanthaspis associated with Callipernurus Whittington, 1956a, Dicranurus Conrad, 1841, Radiaspis Richter \& Richter, 1917, Whittingtonia Prantl \& Prribyl, 1949, and the endemic Hispaniaspis Hammann, 1992 (Hammann 1992). The sudden appearance of Callipernurus, Diacanthaspis, Dicranurus, Radiaspis, and Whittingtonia in the late Katian of Spain (Cystoid Limestone; Hammann 1992) and Sardinia (Portixeddu and 
Domusnovas formations; Hammann \& Leone 2007) indicates a rapid dispersion of the Laurentian and Baltic warm-water elements onto high-latitude shallow shelves with carbonate buildups (Hammann 1992). Their occurrence preceded an abrupt climatic cooling and sea level lowering in the present day Spain and Sardinia at the beginning of the Hirnantian.

Diacanthaspis and Callipernurus are known in the Middle Ordovician of Laurentia (Whittington 1956a). Diacanthaspis is a pandemic genus in tropical and temperate belts. It is known, although often poorly understood (Bruton 1965, 1968; Kielan 1960; Apollonov 1980; Suzuki et al. 2009) from the Lower to the uppermost Ordovician from all palaeocontinents.

Bojokoralaspis probably originated in the early Middle Ordovician in low-latitude (Laurentia or Baltica). This genus, as the new element, appeared in the Prague Basin during the late Sandbian. It may be assumed, that Bojokoralaspis was a new invader into the Prague Basin where Primaspis (with occipital spines) already existed since the early Sandbian. Both genera co-occur herein (Šnajdr 1984) in the late Sandbian to early Katian Zahořany Formation.

Diverse Middle and Upper Ordovician odontopleurid faunas are further known from Baltica, some of them being shared with Laurentia: Acidaspis, Apianurus, Radiaspis and Whittingtonia. None of these genera is known in Middle and Upper Ordovician of the Prague Basin.

\section{Conclusions}

The sudden immigration of Diacanthaspis, Radiaspis and Whittingtonia from Baltica and/or Laurentia and evolution of endemic Hispaniaspis certainly indicates warming and expansion of shallow water carbonate facies in NW Gondwana and European peri-Gondwana (= present day NW Africa and SW Europe). Their immigration into the Prague Basin was much restricted and probably happened later, at least in the now preserved part of the basin.

The Katian global warming and expansion of low-latitude fauna with Heliomera, Ovalocephalus, Staurocephalus, proetids, and odontopleurids into high latitudes (Boucot et al. 2003, Fortey \& Cocks 2005, for alternative interpretation see especially Cherns \& Wheeley 2007) influenced the shelves in NW Gondwana and European terranes on periphery of Gondwana. Similar suitable shelves probably did not border the Prague Basin. When the Hirnantian sea-level lowering has started, the restricted ecospace for the BBP association developed along margins of the Prague Basin for a short time. However, this environment became too cool for immigration of Whittingtonia, Calipernurus, other odontopleurids and majority of other low-latitude trilobite taxa. Only Diacanthaspis and a rare miraspidine Proceratocephala immigrated into the Prague Basin, where Chlustinia and Bojokoralaspis persisted since the Sandbian and/or early Katian, respectively. Despite the short time existence of ecospace suitable for the low-latitude trilobite taxa, also proetids and some other warm to temperate-water elements accompanied the odontopleurid association in the "Perník Bed". Next progressive cooling terminated the short time existing BBP association, and a poor Hirnantia fauna with trilobites Mucronaspis and Eoleonaspis occupied the Prague Basin. It is noteworthy that "Primaspis" evoluta is associated with Mucronaspis mucronata after the decline of the taxonomically rich, earliest Hirnantian fauna with Diacanthaspis, Whittingtonia and Radiaspis (Suzuki et al. 2009) in Dalarna, Sweden. The assumption about cooling in the time and/or immediately before the sedimentation of the "Perník Bed" and its early Hirnantian age is supported by presence of small Eoleonaspis, which is a typical element of the Hirnantia fauna (Kielan 1960, Cocks \& Fortey 2002, see also Mergl 2011a, b, Mitchell et al. 2001, Melchin et al. 2003).

In summary, the available data concerning odontopleurids from the "Perník Bed" support the interpretation, that there were more sources and not only one immigration wave of odontopleurids present. Bojokoralaspis immigrated into the Prague Basin possibly from the Baltica in the late Sandbian or early Katian. Diacanthaspis and Proceratocephala immigrated from Baltica or nearby Avalonia in the latest Katian, likely at the time of the Boda event and persisted here up to the base of the Hirnantian. The last immigrant Eoleonaspis appeared in the Prague Basin in the early Hirnantian together with other elements of the rapidly spreading Mucronaspis fauna (Budil 1996). It is supposed, that all immigrants evolved into particular geographic species in the Prague Basin. Only the very rare Chlustinia? sp. can be assumed to have been derived from ancestors living in the Prague Basin.

In summary, the fauna preserved in the "Perník Bed" is obviously younger than faunas from Spain and Sardinia, which are pre-Hirnantian in age. It is not excluded, that carbonate platform formed outside the range of now preserved Ordovician sediments of the Prague Basin during the supposed warming of the Boda event. However, the origin of the "Perník Bed" reflects sea level lowering, which moved the biofacies belts basinwards. The short-time immigration of "warm-water" elements in the rich BBP fauna indicates none progressive cooling of surface waters at that time. This is contradictory with ideas of Cherns \& Wheeley (2007) but supports well the original concept of Boda event.

\section{Acknowledgements}

The author is greatly appreciated to David Bruton and Helje Parnaste for reviews and comments, which greatly improved the 
text. The author is also indebted to Oldřich Fatka, Petr Štorch, and especially to Petr Budil for loan of material, supply of locality data and inspired critical comments, which significantly improved the quality of this contribution. The research was supported by grant of Academy of Sciences of the Czech Republic, IAA301110908: Faunistická dynamika klimaxového stádia společenstev svrchního ordoviku před globální krizí způsobenou klimatickými změnami: záznam z králodvorského souvrství Barrandienu. This is a contribution to IGCP Project 591: The Early to Middle Palaeozoic Revolution.

\section{References}

Apollonov, M.K., Bandaletov, S.M. \& Nikitin, I.F. 1980. Granica ordovika i silura v Kazakhstane. 300 pp. Izdatelstvo Nauka Kazakhskoy SSR, Alma-Ata.

BARRANDE, J. 1846. Nouveaux trilobites. Supplément sur le Notice préliminaire sur le Système silurien et des trilobites de Bohême. 91 pp. Calve, Prague.

BARRANDE, J. 1852. Systême silurien du centre de la Bohême. Ière partie. Recherches paléontologiques. I. Trilobites. $935 \mathrm{pp}$. Privately published, Prague \& Paris. DOI 10.5962/bhl.title.14776

BARRANDE, J. 1872. Système silurien du centre de Bohême. Supplément au vol. I - Trilobites, Crustacés divers et Poissons. 647 pp. Privately published, Prague.

Boucot, A.J., Rong, J.Y., Chen, X. \& Scotese, C.R. 2003. Pre-Hirnantian Ashgill climatically warm event in the Mediterranean region. Lethaia 36(2), 119-132. DOI 10.1080/00241160310001245

Brenchley, P.J. \& Štorch, P. 1989. Environmental changes in the Hirnantian (upper Ordovician) of the Prague Basin, Czechoslovakia. Geological Journal 24(3), 165-181. DOI 10.1002/gj.3350240302

Bruton, D.L. 1965. The Middle Ordovician of the Oslo Region, Norway. 19. The trilobite family Odontopleuridae. Norsk Geologisk Tidsskrift 45, 339-356.

BRuton, D.L. 1966. A revision of the Swedish Ordovician Odontopleuridae (Trilobita). Bulletin of the Geological Institutions of the University of Uppsala 43(8), 1-40.

Bruton, D.L. 1968. Ordovician odontopleurid trilobites from Estonia and Latvia. Lethaia 1(3), 288-302. DOI 10.1111/j.1502-3931.1968.tb01742.x

BRUTON, D.L. 2008. A systematic revision of Selenopeltis (Trilobita: Odontopleuridae) with description of new material from the Ordovician Anti Atlas region, Morocco. Paläontologische Zeitschrift 82(1), 1-16. DOI 10.1007/BF02988429

Budil, P. 1996. Representatives of genera Mucronaspis and Songxites (Trilobita) from the Bohemian Upper Ordovician. Journal of the Czech Geological Society 41(1), 63-78.

Budil, P., Fatka, O., Kolár̆, P. \& David, M. 2011a. Arthrorhachis Hawle \& Corda, 1847 (Agnostida) in the Prague Basin (Barrandian area, Czech Republic) revisited. Bulletin of Geosciences 86(4), 707-724. DOI 10.3140/bull.geosci.1262

Budil, P., Fatka, O., Mergl, M. \& David, M. 2011b. Trilobite biostratigraphy of the Králův Dvůr Formation (upper Katian, Prague Basin, Czech Republic): global faunal changes or facies-related distribution? Geologické výzkumy na Moravě a ve Slezsku 18(1), 4-10.

Burmeister, H. 1843. Die Organisation und Uebersicht der Trilobiten. XIII + 148 pp. Georg Reimer, Berlin.

Cherns, L. \& Wheeley, J.R. 2007. A pre-Hirnantian (Late Ordovician) interval of global cooling - The Boda event re-assessed. Palaeogeography, Palaeoclimatology, Palaeoecology 251, 449-460. DOI 10.1016/j.palaeo.2007.04.010

Cocks, L.R.M. \& ForteY, R.A. 2002. The palaeogeographical significance of the latest Ordovician fauna from the Panghsapye Formation of Burma. Special Papers in Palaeontology 67, 57-76.

Cocks, L.R.M. \& PRICE, D. 1975. The biostratigraphy of the upper Ordovician and Lower Silurian of south-west Dyfed, with comments on the Hirnantia Fauna. Palaeontology 18(4), 703-724.

Colmenar, J., Villas, E. \& Vizcaïno, D. 2013. Upper Ordovician brachiopods from the Montagne Noire (France): endemic Gondwanan predecessors of Prehirnantian low-latitude immigrants. Bulletin of Geosciences 88(1), 153-174.

ConRad, T.A. 1841. Description of new genera and species of organic remains Crustacea. New York Geological Survey, $5^{\text {th }}$ Annual Report, 25-57.

Curtis, N.J. \& Lane, P.D. 1998. The Llandovery trilobites of England and Wales. Part 2. Monograph of the Palaeontographical Society 152, 51-101.

FatKa, O. \& Mergl, M. 2009. The 'microcontinent' Perunica: status and story 15 years after conception. Geological Society, London, Special Publications 325, 65-101. DOI 10.1144/SP325.4

Ferretti, A. 1998. Late Ordovician conodonts from the Prague Basin. Palaeontologia Polonica 58, 123-139.

Fortey, R.A. \& Cocks, L.R.M. 2005. Late Ordovician global warming - The Boda event. Geology 33(5), 405-408. DOI $10.1130 / \mathrm{G} 21180.1$

FRÝDA, J. 1989. A new species of Mimospira (Clisospiridae, Gastropoda) from the late Ordovician of Bohemia. Věstník Ústředního ústavu geologického 64(4), 237-241.

Hammann, W. 1992. The Ordovician trilobites from the Iberian Chains in the province of Aragón, NE-Spain. I. The trilobites of the Cystoid Limestone (Ashgill Series). Beringeria 6, 1-220.

Hammann, W. \& Leone, F. 2007. Trilobite from the post-sardic (Upper Ordovician) sequence of southern Sardinia. Part 2. Beringeria 38, 1-139.

HAvLíčEK, V. 1967. Brachiopoda of the suborder Strophomenidina in Czechoslovakia. Rozpravy Ústředního ústavu geologického 33, 1-235.

HavlíčEK, V. 1977. Brachiopods of the order Orthida in Czechoslovakia. Rozpravy Ústředního ústavu geologického 44, $1-327$.

HavlíčEK, V. 1981. Upper Ordovician brachiopods from the Montagne Noire. Palaeontographica A 176, 1-34.

HavlíčEK, V. 1982. Ordovician in Bohemia: development of the Prague Basin and its benthic communitites. Sborník geologických věd, Geologie 37, 103-136. 
HAVLíčEK, V. 1989. Climatic changes and development of benthic communities through the Mediterranean Ordovician. Sborník geologických věd, Geologie 44, 79-116.

HavlíčeK, V. \& Mergl, M. 1982. Deep water shelly fauna in the latest Kralodvorian (upper Ordovician, Bohemia). Věstník Ústředního ústavu geologického 57(1), 37-46.

HAVlíčEK, V. \& ŠTORCH, P. 1990. Storm sandstones and benthic fauna of the Zahořany Formations in Prague. Věstník Ústředního ústavu geologického 65(3), 167-172.

HAVLÍ̌̌EK, V. \& VANĚK, J. 1966. The biostratigraphy of the Ordovician of Bohemia. Sborník geologických věd, Paleontologie $8,7-69$.

HavlíčEK, V., VAnĚK, J. \& FatKa, O. 1994. Perunica microcontinent in the Ordovician (its position within the Mediterranean Province, series division, benthic and pelagic associations). Sborník geologických věd, Geologie 46, 23-56.

Hawle, I. \& Corda, A. J. C. 1847. Prodrom einer Monographie der böhmischen Trilobiten. Abhandlungen der Königlichen Böhmischen Gesellschaft der Wissenschaft 5, 1-176.

Jell, P.A. \& Adrain, J.M. 2002. Available generic names for trilobites. Memoirs of the Queensland Museum 48(2), 331-553.

JimÉnEZ-SÁnChES, A., SpJeldnÆS, N. \& Villas, E. 2007. Ashgill bryozoans from the Iberian Chains (NE Spain) and their contribution to the Late Ordovician biodiversity peak in North Gondwana. Ameghiniana 44(4), 681-696.

KIELAN, Z. 1960. Upper Ordovician trilobites from Poland and some related forms from Bohemia and Scandinavia. Palaeontologia Polonica 11, 1-198.

Koren', T.N., Mikhaylova, N.F. \& Tzai, D.T. 1980. Class Graptolithina, 212-170. In Appolonov, M.K., BANDAletov, S.M. \& Nikitin, I.F. (eds) Granitsa ordovika i silura v Kazakhstane. Izdatel'stvo Nauka Kazakhskoy SSR, Alma Ata.

Leone, F., Hammann, W., Laske, R., Serpagli, E. \& Villas, E. 1991. Lithostratigraphic units and biostratigraphy of the postSardic Ordovician sequence in south-west Sardinia. Bollettino della Società Paleontologica Italiana 30(2), 201-235.

Lespérance, P.J. \& Sheehan, P.M. 1987. Trilobites et Brachiopodes ashgilliens (Ordovicien supérieur) de 1 "Assise" de Fosse, Bande des Sambre-Meuse (Belgique). Bulletin de l'Institut Royal des Sciences Naturelles de Belgique, Sciences de la Terre 57, 91-123.

MAReK, L. 1951. Nové nálezy ve vrstvách kosovských $\left(\mathrm{d} \zeta_{2}\right)$. Sborník Ústředního ústavu geologického 18, 233-244.

MAREK, L. 1952. Příspěvek ke stratigrafii a fauně nejvyšší části břidlic králodvorských $\left(\mathrm{d} \zeta_{1}\right)$. Sborník Ústředního ústavu geologického, Oddíl paleontologický 19, 429-455.

MareK, L. 1964. Shumardia Billings, 1862 a Staurocephalus Barrande, 1846 (Trilobita) v českém ordoviku. Časopis Národního muzea, Oddíl př́rodovědný 133(3), 153-154.

MAREK, L. 1989. The hyoliths of the Králův Dvůr Formation (Bohemian Ordovician). Sborník geologických věd, Paleontologie $30,37-59$.

M'Coy, F. 1851. On some new Cambro-Silurian fossils. Annals and Magazine of Natural History (series 2) 8, 387-409.

Melchin, M.J., Mitchell, C.E., Holmden, C. \& S̆Torch, P. 2013. Environmental changes in the Late Ordovician-early Silurian:
Review and new indisghts from black shales and nitrogen isotopes. Geological Society of America Bulletin 125(11/12), 1635-1670. DOI 10.1130/B30812.1

Mergl, M. 2011a. Earliest occurrence of the Hirnantia Fauna in the Prague Basin (Czech Republic). Bulletin of Geosciences 86(1), 63-70. DOI 10.3140/bull.geosci.1245

Mergl, M. 2011b. Diverzita mechovek (Bryozoa) v nejvyšší části králodvorského souvrství (ordovik; svrchní katian) pražské pánve České republiky. Zprávy o geologických výzkumech v roce $2010,100-102$.

Mergl, M. 2011c. Faunal turnover near the Katian/Hirnantian boundary in the Prague Basin (Czech Republic), 359-366. In Gutiérrez-Marco, J.C., Rábano, I., Gozalo, R. \& GarciaBellido, D. (eds) Ordovician of the World. Cuadernos del Museo Geominero 14. Instituto Geologico y Minero de España, Madrid.

Mergl, M. 2012. Lingulate and craniate brachiopods from the top of the Králův Dvůr Formation (latest Katian) and their contribution to palaeogeography. Acta Musei nationalis Pragae, Series $B$ - historia naturalis 68(1-2), 35-46.

Mitchell, C.E., Štorch, P., Holmden, C., Melchin, M.J. \& GutiérReZ-MARCo, J.C. 2011. New stable isotope data and fossils from the Hirnantian Stage in Bohemia and Spain: implication for correlation and palaeoclimate, 371-378. In Gutiérrez-Marco, J.C., RÁbano, I. \& García-Bellido, D. (eds) Ordovician of the World. Cuedernos del Museo Geominero 14. Instituto Geológico y Minero de Espańa, Madrid.

Prantl, F. \& PřIBYL, A. 1949. Studie o trilobitech nadčeledi Odontopleuracea nov. superfam. Rozpravy Státního geologického ústavu Československé republiky 12, 1-221.

PeK, I. \& VANĚK, J. 1989. Index of Bohemian trilobites. 65 pp. Krajské vlastivědné muzeum, Olomouc.

Popov, L.E., Holmer, L.E., Bassett, M.G., Ghobadi Pour, M. \& Percival, I. 2013. Biogeography of Ordovician linguliform and craniiform brachiopods, 117-126. In HARPER, D.A.T. \& Servais, T. (eds) Early Palaeozoic Palaeobiogeography and Palaeogeography. Geological Society of London, Memoirs 38.

PrICE, D. 1980. Ashgill trilobite faunas from the Llyns peninsula, North Wales. Geological Journal 16, 201-216. DOI $10.1002 / \mathrm{gj} .3350160305$

Pর̌IBYL, A. \& VANĚK, J. 1965. Neue Trilobiten der böhmischen Ordoviziums. Věstník Ústředního ústavu geologického 40(4), 277-282.

PřIBYL, A. \& VANĚK, J. 1966. Zum Kenntnis zum Odontopleuridae-Trilobiten aus dem böhmischen Altpaläozoikum. Acta Universitatis Carolinae, Geologica 4, 289-304.

RAmsköld, L. \& Chatterton, B.D.E. 1991. Revision and subdivision of the polyphyletic "Leonaspis" (Trilobita). Transactions of the Royal Society of Edinburgh, Earth Sciences 82, 333-371. DOI 10.1017/S026359330000420X

REED, F.R.C. 1905. New fossils from the Haverfordwest District. Geological Magazine 5(2), 97-104.

DOI 10.1017/S0016756800129450

ReED, F.R.C. 1914. The Lower Palaeozoic trilobites of Girvan. Supplement. Monograph of the Palaeontographical Society of London, 1-56.

REED, F.R.C. 1915. Supplementary memoir on new Ordovician 
and Silurian fossils from the Northern Shan States. Palaeontologia Indica (New Series) 6(1), 1-98.

Richter, R. \& Richter, E. 1917. Ueber die Einteilung der Familie Acidaspidae und über einige ihrer devonischen Vertreter. Centralblatt für Mineralogie, Geologie und Paläontologie, Jahrg. 1917, 432-472.

Shaw, F.C. 1995. Ordovician trinucleid trilobites of the Prague Basin, Czech Republic. The Paleontological Society, Memoir $40(4), 1-23$.

SHAw, F.C. 2000. Trilobites of the Králův Dvůr Formation (Ordovician) of the Prague Basin, Czech Republic. Věstník Českého geologického ústavu 75(4), 371-404.

SHENG, X.F. 1974. Classification and correlation of Chinese Ordovician Series. 152 pp. Earth Science Publishing House, Beijing.

$\breve{S}_{\text {NAJDR, M. }}$ 1982. New trilobites from the Bohdalec Formation (Berounian) in the Barrandium. Věstník Ústředního ústavu geologického 57(4), 227-230.

ŠNAJDR, M. 1984. Bohemian Ordovician Odontopleuridae (Trilobita). Sborník geologických věd, Paleontologie 26, 47-82.

ŠNAJDR, M. 1987. New odontopleurid trilobite from the Kosov Formation (Ashgill, Bohemia). Časopis pro mineralogii a geologii 32(3), 303-304.

S̆тоRCH, P. 2006. Facies development, depositional settings and sequence stratigraphy across the Ordovician-Silurian boundary: a new perspective from the Barrandian area of the Czech Republic. Geological Journal 41(2), 163-192. DOI 10.1002/gj.1038

Štorch, P. \& Mergl, M. 1989. Králodvor/Kosov boundary and the late Ordovician environmental changes in the Prague Basin (Barrandian area, Bohemia). Sborník geologických věd, Geologie 44, 117-153.

Suzuki, Y., ShiIno, Y. \& Bergström, J. 2009. Stratigraphy, carbonate facies and trilobite associations in the Hirnantian part of the Boda Limestone, Sweden. Geologiska Föreninges i Förhandlingar 131, 299-310.

Temple, J.T. 1965. Upper Ordovician brachiopods from Poland and Britain. Acta Palaeontologica Polonica 10(3), 379-427.

Temple, J.T. 1969. Lower Llandovery (Silurian) trilobites from Keisley, Westmorland. Bulletin of the British Museum (Natural History), Geology 18, 199-230.

TÖRNQUIST, S.V. 1884, Undersökningar öfver Siljanomrädets Trilobitfauna. Sveriges Geologiska Undersökning, Serie C 66, $1-101$.

Troedsson, G.T. 1918. Om Skanes Brachiopodskiffer. Lunds Universitets Arsskrifter 2, 15(3), 1-104.
VANĚK, J. 2001. Remarks to the article F.C. Shaw: Trilobites of the Králův Dvůr Formation (Ordovician) of the Prague Basin, Czech Republic. Palaeontologia Bohemiae 7, 65-71.

VANĚK, J. \& VALÍČEK, J. 2001. New index of genera, subgenera and species of Barrandian trilobites. Part A-B (Cambrian and Ordovician). Palaeontologia Bohemiae 7, 1-49.

Vennin, E., Álvaro, J.J. \& Villas, E. 1998. High-latitude pelmatozoan-bryozoan mud-mounds from the late Ordovician northern Gondwana platform. Geological Journal 33, 121-140. DOI 10.1002/(SICI)1099-1034(1998040)33:2<121:: AID-GJ780>3.0.CO;2-D

VILLAS, E. 1985. Braquipodos del Ordovicio Medio y Superior de las Cadenas Ibericas Orientales. Memorias del Museo Paleontologico de la Universidad de Zaragoza 1, 1-153.

ViLLAS, E. 1995. Caradoc through Early Ashgill brachiopods from the Central-Iberian Zone (Central Spain). Geobios 28(1), 49-84. DOI 10.1016/S0016-6995(95)80204-5

Villas, E., Vennin, E., Álvaro, J.J., Hammann, W., Herrera, Z.A. \& Piovano, E.L. 2002. The late Ordovician carbonate sedimentation as a major trigerring factor of the Hirnantian glaciation. Bulletin de la Société géologique de France 173, 569-578. DOI 10.2113/173.6.569

Villas, E., Vizcaïno, D., Álvaro, J.J., Destombes, J. \& Vennin, E. 2006. Biostratigraphic control of the latest-Ordovician glaciogenic uncorfomity in Alnif (Eastern Anti-Atlas, Morocco), based on brachiopods. Geobios 39(5), 727-737. DOI 10.1016/j.geobios.2005.05.003

Whittington, H.B. 1941. Silicified Trenton trilobites. Journal of Paleontology 15(5), 492-522.

Whittington, H.B. 1956a. Silicified Middle Ordovician trilobites: The Odontopleuridae. Bulletin of the Museum of Comparative Zoology at Harward college 114(5), $155-288$.

Whittington, H.B. 1956b. Type and other species of Odontopleuridae (Trilobita). Journal of Paleontology 30(3), 504-520.

Whittington, H.B., Chatterton, B.D.E., Speyer, S.E., Fortey, R.A., Owens, R.M., Chang, W.T., Dean, W.T., Jell, P.A., Laurie, J.R., Palmer, A.R., Repina, L.N., Rushton, A.W.A., Shergold, J.H., Clarkson, E.N.K., Wilmot, N.V. \& Kelly, S.R.A. 1997. In KAESLER, R.L. (ed.) Treatise on Invertebrate Paleontology, Part O, Revised, Trilobita. Introduction, Order Agnostida, Order Redlichiida, Volume 1. xxiii + 530 pp. Geological Society of America \& University of Kansas, Boulder \& Lawrence. 